\title{
Bone Health in Patients of Chronic Myeloid Leukemia on Imatinib Therapy
}

Dr. Ajay Yadav ${ }^{1 *}$, Dr. Munmun Yadav ${ }^{2}$

${ }^{1}$ Assistant Professor, Department of Medical Oncology, Mahatma Gandhi Medical College and Hospital, MGUMST, Jaipur, Rajasthan, India

${ }^{2}$ Senior Lecturer, Department of Periodontology and Oral Implantology, Mahatma Gandhi Dental College and Hospital, Jaipur, Rajasthan, India

DOI: $10.36347 /$ sjams.2021.v09i03.019

| Received: 21.02.2021 | Accepted: 09.03.2020 | Published: 11.03.2021

*Corresponding author: Dr. Ajay Yadav

Abstract

Original Research Article

Background: Long term toxicities of imatinib are important as patients need to take it for a long duration probably for lifetime. Effect of imatinib on serum calcium and phosphate has been shown in few studied. We planned this study to evaluate the effect of imatinib on bone health. Material and Methods: In this study bone health of 104 patients of CML and 104 normal healthy individuals was assessed and compared by Serum Calcium, Serum Magnesium, Serum Phosphorus, Serum Vitamin D, Serum Alkaline phosphatase, and DEXA scan. Results: Mean serum calcium level was $9.25 \mathrm{mg} / \mathrm{dl}$ in CML patients and $9.53 \mathrm{mg} / \mathrm{dl}$ in normal healthy individuals ( $\mathrm{p}$ value $<.01$ ). Level of serum phosphorus was $2.15 \mathrm{mg} / \mathrm{dl}$ in CML patients versus $3.41 \mathrm{mg} / \mathrm{dl}$ in normal controls ( $\mathrm{p}$ value $<.001$ ). Mean serum vitamin $\mathrm{D}$ level of CML patients was $27.96 \mathrm{ng} / \mathrm{ml}$ versus $23.85 \mathrm{ng} / \mathrm{ml}$ ( $\mathrm{p}$ value <.01). Mean BMD of CML patients was -0.83 versus 0.99 in normal individuals. ( $\mathrm{p}$ value > .05). Conclusion: Long term use of imatinib in CML patients affects the bone health significantly and may impact the quality of life.

Keywords: Bone Health, Imatinib Therapy, CML patients.

Copyright $\odot 2021$ The Author(s): This is an open-access article distributed under the terms of the Creative Commons Attribution 4.0 International License (CC BY-NC 4.0) which permits unrestricted use, distribution, and reproduction in any medium for non-commercial use provided the original author and source are credited.

\section{INTRODUCTION}

Imatinib mesylate is a potent inhibitor of all ABL tyrosine kinases (c-ABL, BCR-ABL and Tel/ABL) and ABL-Related Gene (ARG) [1]. Imatinib binds at the ATP binding site of kinase domain. It is currently the "gold standard" treatment for Philadelphia chromosome-positive chronic myeloid leukemia (CML) in chronic phase. Although imatinib was designed to specifically target BCR-Abl, many offtarget kinases are affected by imatinib actively [2]. Considering the wide range of signalling pathways inhibited by imatinib, one might expect that imatinib therapy would be associated with severe adverse effects. As imatinib is required for life-long therapy for CML patients, its long-term toxicities are more important. Berman and co-workers [3] found that imatinib treated patients had hypophosphatemia, lower osteocalcin levels and higher parathyroid hormone levels. Subsequent studies confirmed the observation of hypophosphatemia in patients receiving imatinib. The authors concluded that imatinib may affect bone remodelling and if left untreated, chronic hypophosphatemia may result in impaired bone mineralization, rickets, and osteomalacia. These findings were explained by an imatinib induced inhibition of bone turnover, which in turn, triggered a secondary hyperparathyroidism in an attempt to maintain calcium homeostasis.

According to Jonsson et al. [4] both osteoblasts and osteoclasts are targeted by imatinib and it has been shown that imatinib promotes osteoblast differentiation and inhibits osteoclastogenesis, presumably through its action on the colony-stimulating factor 1 receptor $(\mathrm{C}$ FMS) and platelet derived growth factor receptor (PDGFR). Overall, biochemical findings suggest a suppressed bone turnover and the increased BMD indicates that bone formation and resorption are affected unequally. It has been suggested that imatinib uncouples bone formation from bone resorption in favour of the former, disturbing bone homeostasis and leading to a net increase in bone mineral density. This is further supported by a recent study by Fitter et al. [5], who reported an increased trabecular bone volume in imatinib treated patients. We planned this study to determine the bone health in patients of CML receiving imatinib.

Aim of this study was to determine bone marrow density as assessed by DEXA scan in patient of chronic myeloid leukemia on imatinib therapy. 
Ajay Yadav \& Munmun Yadav; Sch J App Med Sci, Mar, 2021; 9(3): 390-392

Bone health markers (serum calcium, phosphorus and vitamin $\mathrm{D}_{3}$ level) in patient of chronic myeloid leukemia on imatinib therapy.

\section{Material And Methods}

This was a hospital based observational study. Study was conducted on 104 patients of chronic myeloid leukaemia who were on imatinib for at least last one year and controls were 104 normal healthy subjects. Cases were taken from patients of CML attending Leukaemia Lymphoma Clinic at Birla Cancer Centre, Medical OPD and wards SMS Hospital, Jaipur and controls were healthy individuals taken from general population. Patients gave their informed consent and local ethical committee approved the protocol. Patients with a known parathyroid disorder, active thyroid disorder, and any renal disease were excluded. Patients taking oral calcium and vitamin D supplements or taking oral or intravenous steroids, calcitonin, any selective oestrogen modulating agent such as tamoxifen or raloxifene were also excluded.

Study size is estimated at $80 \%$ power of study and alfa error 0.05 assuming standard deviation of bone marrow density as $0.1 \mathrm{gm} / \mathrm{cm}^{2}$ and minimum difference to be calculated of $0.05 \mathrm{gm} / \mathrm{cm}^{2}$. Sample size thus obtained comes to 64 in each group.

These patients underwent complete clinical assessment and investigations including haemoglobin, total leucocyte count, platelet count, ESR, Serum Calcium, Serum Magnesium, Serum Phosphorus, Serum Vitamin D, Serum Alkaline phosphatase, Thyroid Profile $\left(\mathrm{T}_{3} / \mathrm{T}_{4} \mathrm{TSH}\right)$, DEXA Scan.

\section{RESULTS}

Mean age of 104 cases of CML was $33.72 \pm$ 12.82 years while mean age of 104 normal healthy subjects was $33.73 \pm 12.78$ years. Out of 104 cases of CML 64 were males and 40 were females while out of 104 normal healthy subjects 64 were males and 40 were females. Mean serum calcium level 104 patients of CML was $9.25 \pm 0.71 \mathrm{mg} / \mathrm{dl}$. Mean serum calcium of normal healthy individuals was $9.53 \pm 0.64 \mathrm{mg} / \mathrm{dl}$. This difference was statistically significant $(\mathrm{p}$ value $<.01$ ). Mean serum phosphorus of cases was $2.15 \pm 0.29$ $\mathrm{mg} / \mathrm{dl}$. Mean serum phosphorus of normal healthy individuals was $3.41 \pm 0.52 \mathrm{mg} / \mathrm{dl}$. This difference was statistically highly significant $(\mathrm{p}$ value $<.001$ ). Mean serum vitamin D of 104 CML patients was $27.96 \pm 10.86$ $\mathrm{ng} / \mathrm{ml}$. Mean serum vitamin $\mathrm{D}$ of normal healthy individuals was $23.85 \pm 8.13 \mathrm{ng} / \mathrm{ml}$. This difference was statistically significant ( $\mathrm{p}$ value $<.01$ ). Mean BMD of cases was $-0.83 \pm 1.38$. Mean BMD of normal healthy individuals was $-0.99 \pm 1.78$. This difference was statistically nonsignificant ( $\mathrm{p}$ value> .05). Mean serum magnesium of cases was $2.84 \pm 0.70 \mathrm{mg} / \mathrm{dl}$. Mean serum magnesium of normal healthy individuals was
$2.19 \pm 0.26 \mathrm{mg} / \mathrm{dl}$. This difference was statistically highly significant ( $\mathrm{p}$ value $<.001)$.

\section{DisCUSSION}

Many efforts have been made to study the effect of imatinib on bone and mineral metabolism. A principal study was conducted by Berman et al.[6]. Berman et al. first demonstrated that serum level of osteoclast marker N-teloopeptide of collagen crosslinks (NTX) were decreased in imatinib treated CML and GIST patients, relative to healthy controls [6]. O'Sullivan et al. [7] prospectively studied biochemical indexes of calcium metabolism in blood and urine samples obtained after an overnight fast from nine patients (six men and three women, with a mean $[ \pm \mathrm{SD}]$ age of $46 \pm 10$ years) who had the $B C R-A B L$ mutation and were starting imatinib therapy (at a dose of $400 \mathrm{mg}$ daily) for chronic myeloid leukemia. These changes in bone turnover were accompanied by a reduced serum calcium level, secondary hyperparathyroidism, phosphaturia, and a reduced serum phosphate level. Jönsson et al. [8] found that imatinib treated CML patients had significantly higher BMD of the lumbar spine $(+12 \%)$ and total hip bone $(+12 \%)$ compared with controls.

The present study was conducted on 104 patients of chronic myeloid leukaemia and 104 normal healthy subjects. These patients underwent complete clinical assessment and bone health was assessed by Serum Calcium, Serum Magnesium, Serum Phosphorus, Serum Vitamin D, Serum Alkaline phosphatase, Thyroid Profile $\left(\mathrm{T}_{3} / \mathrm{T}_{4} / \mathrm{TSH}\right)$, DEXA Scan.

In this study both the arms were well balanced according to age and sex. Healthy individuals having disease or drugs affecting bone density were excluded. In this study mean serum calcium level 104 patients of CML was $9.25 \pm 0.71 \mathrm{mg} / \mathrm{dl}$. Range of serum calcium was $7-10.4 \mathrm{mg} / \mathrm{dl}$. Mean serum calcium of normal healthy individuals was $9.53 \pm 0.64 \mathrm{mg} / \mathrm{dl}$. This difference in serum calcium of cases and normal healthy individuals was found to be statistically significant $(\mathrm{p}$ value $<.01)$

Serum vitamin D of 104 CML patients was $27.96 \pm 10.86 \mathrm{ng} / \mathrm{ml}$. Mean serum vitamin $\mathrm{D}$ of normal healthy individuals was $23.85 \pm 8.13 \mathrm{ng} / \mathrm{ml}$. This difference in serum vitamin $\mathrm{D}$ of cases and normal healthy individuals was found to be statistically significant ( $\mathrm{p}$ value $<.01)$.

In this study mean BMD of cases was -0.83 with standard deviation 1.38. Mean BMD of normal healthy individuals was -0.99 with standard deviation 1.78. This difference in serum BMD of cases and normal healthy individuals was found to be statistically non-significant ( $\mathrm{p}$ value $>.05$ ). 


\section{Conclusion}

Long-term toxicity of the imatinib affects the quality of life of CML patients. In this study significant hypocalcemia and hypophosphatemia was noticed in patients of CML on imatinib therapy. Imatinib mesylate significantly modulates bone turnover, as evidenced by an increase in serum vitamin D and lowered levels of serum calcium and phosphate. Routine monitoring of serum phosphate and vitamin D during imatinib therapy may be advisable so that prompt phosphate replacement can be initiated.

Chronic, untreated hypophosphatemia can result in impaired bone mineralization, rickets, and osteomalacia. This study suggests that patient management and care should include appropriate monitoring of skeletal health. Further study in this area may be important.

\section{REFERENCES}

1. Buchdunger E, Zimmermann J, Mett H, Meyer T, Müller M, Druker BJ, Lydon NB. Inhibition of the $\mathrm{Abl}$ protein-tyrosine kinase in vitro and in vivo by a 2-phenylaminopyrimidine derivative. Cancer research. 1996 Jan 1;56(1):100-4.

2. Rix U, Hantschel O, Dürnberger G, Remsing Rix LL, Planyavsky M, Fernbach NV, and Kaupe I, Bennett KL, Valent $P$, Colinge J, Köcher T. Chemical proteomic profiles of the BCR-ABL inhibitors imatinib, nilotinib, and dasatinib reveal novel kinase and nonkinase targets. Blood. 2007 Dec 1; 110(12):4055-63.

3. Berman E, Nicolaides M, Maki RG, Fleisher M, Chanel S, Scheu K, Wilson BA, Heller G, Sauter NP. Altered bone and mineral metabolism in patients receiving imatinib mesylate. New England Journal of Medicine. 2006 May 11;354(19):200613.

4. Jonsson S, Olsson B, Ohlsson C, Lorentzon M, Mellstrom D, Wadenvik H. Increased cortical bone mineralization in imatinib treated patients with chronic myelogenous leukemia. Haematologica. 2008;93(7):1101-1103.

5. Fitter S, Dewar AL, Kostakis P, To LB, Hughes $\mathrm{TP}$, and Roberts MM. Long term imatinib therapy promotes bone formation in CML patients. Blood. 2008; 111:2538-47.

6. Berman E, Nicolaides M, Maki RG. Altered bone and mineral metabolism in patients receiving imatinib mesylate. N Engl J Med. 2006; 354:20062013.

7. O'Sullivan S, Horne A, Wattie D. Decreased bone turnover despite persistent secondary hyperparathyroidism during prolonged treatment with imatinib. J Clin Endocrinol Metab. 2009; 94(4):1131-1136.

8. Jo"nsson S, Olsson B, Ohlsson C, Lorentzon M, Mellstro"m D, Wadenvik H. Increased cortical bone mineralization in imatinib treated patients with chronic myelogenous leukemia. Haematologica. 2008; 93(7):1101-1103. 